\title{
Influence of Nanoparticles on the Growth, Development and Germination of Plants and Their Subsequent Effects on the Environment: A Review
}

\author{
Faran Mustafa'*, Abu Al Hussain², M Zargham Ali², Shaheera Qureshi², Asma Arif', Hafiz \\ Muhammad Zia Ullah Ghazali ${ }^{3}$ and Muhammad Sajjad ${ }^{4}$ \\ ${ }^{1}$ Institute of Soil and Environmental Sciences, University of Agriculture Faisalabad, Pakistan \\ ${ }^{2}$ Department of Plant Breeding and Genetics, Pir Mehr Ali Shah Arid Agriculture University Rawalpindi, Pakistan \\ ${ }^{3}$ Oilseeds Research Institute, Faisalabad, Pakistan \\ ${ }^{4}$ Department of Biosciences, COMSATS University Islamabad, Pakistan
}

*Corresponding author: Faran Mustafa, Institute of Soil and Environmental Sciences, University of Agriculture Faisalabad, Pakistan

\section{ARTICLE INFO}

Received: 幽 November 24, 2021

Published: 幽 December 01, 2021

Citation: Faran Mustafa, Abu Al Hussain, M Zargham Ali, Shaheera Qureshi, Asma Arif, et al., Influence of Nanoparticles on the Growth, Development and Germination of Plants and Their Subsequent Effects on the Environment: A Review. Biomed J Sci \& Tech Res 40(2)-2021. BJSTR. MS.ID.006432.

\begin{abstract}
Rapid developments and advancements in the field of nanotechnology by every passing day continuously add up engineered nanoparticles in our existing system which itself has a remarkable contribution in the pharmaceutical sciences, biofuel industry, plant biotechnology, electronics, nanomedicine, cosmetics, and various other domains. In this review article, we pronounce on the importance of nanoparticles in the development and growth of plants, highlighting their advantageous and detrimental side impacts. These impacts have been evaluated utilizing cytogenic studies on plants, by researching the influence of carbon nanotubes on plant growth and by studying the gene delivery procedure deploying mesoporous silica nanoparticles as transporter or as biomolecule delivery vehicles. On the other hand, when the concentration of nanomaterials remains unchecked, then nanomaterials would undoubtedly produce toxicity up to a dangerous level. It may show negative effects like decreased plant growth, adverse effects on human health and environment, reduced chlorophyll synthesis etc. Nanoparticles may pose harmful and beneficial effects on plant health which may vary from specie to specie along with the NPs concentration and its type used.
\end{abstract}

\section{Introduction}

Nanotechnology is an innovative captivating and advancing discipline of science. Innovations and developments in the field of nanotechnology might unfold new usages in the discipline of agriculture and plant biotechnology. It endorses enhanced research in many fields. Recent breakthroughs in the field of nanotechnology bestowed high-tech platforms and information for many usages in defense sectors, medical science, electronics, and aerospace [1]. It is acknowledged that nanomaterials impart several exclusive magnetic, mechanical, optical, chemical and physical attributes that bestow numerous pros and sanctions them to be extensively utilized in food, bioengineering, materials, medicine and chemicals, and in many other areas. Owing to accomplishment of use of nanotechnology in these fields, curiosity has been raised in introducing this technique of nanotechnology in food systems and agriculture [2]. The engineered nanomaterials are capable to pierce into the leaves and cells of plants, and they ca also transfer chemicals and DNA into the cells of plant [3-5]. This attribute of nanotechnology confers novel prospects in biotechnology for alteration in particular genes and gene expression in the certain plant cells. Recently, there has been an escalation in usage of 
nanoparticles in biofuel industry, biotechnology, plant production for non-edible usages and management of crops due to advent of findings of the distinctive applications of nanomaterials on the cells of plants and on entire plants. Though, toxicity instigated by nanoparticles to living beings and their influence on the environment is one of the vital concerns that has to be attended to direct studies on efficacious usages of nanoparticles [6].

The aquatic and terrestrial ecosystems may be adulterated by the substantial production of engineered nanoparticles for various uses according to the latest studies [7]. The modifications in structure and physiological attributes and substantial size reduction of artificial nanoparticles may bring about arbitrary effects on humans, animals, and plants [8-10]. Nanotechnology has huge aptitude to bestow a prospect for the plant science researchers and scientists of other disciplines to exploit novel tools for penetration of nanomaterials into plant cells that might ameliorate present roles and supplement new ones [11]. In this review article, we will elaborate on the contemporary advancements in plant science that emphasizes on the probable harmful and helpful functions of nanoparticles (NPs) contributing to the development and growth in plants and as biomolecule delivery vehicles.

\section{Cytogenetic Studies in Plants Involving Nanoparticles}

Numerous areas such as medicine, electronics and cosmetics involve the use of NPs [12]. Queries that how the employments of NPs may influence the environment regardless of its apparent advantages still exist. NPs become part of the environment during production, use or disposal in-deliberately because of its vast useage. Toxic effects are discovered in plants and other organism due to excessive production of NPs [13]. As a consequence of this phytotoxicity in crop plants human health can face excessive threats via the food chain [14]. Regardless of the fact, phytotoxicity caused by NPs in plant have been witnessed by various researchers [15-17]. Surface charge, $\mathrm{pH}$ and the environment size have also a huge role on the toxicity of NPs [18-20]. There are four groups into which the engineered NPs are divided: Carbon-based materials, Dendrimers, Composites and Metal-based materials [21]. NPs impinges the growth of higher plants, for example, corn, cucumber, and soybean when grown in soil treated with nano- scale alumina (nano- $\mathrm{Al}_{2} \mathrm{O}_{3}$ ) exhibits the inhibition of root elongation [22] Table 1. Phytotoxic characteristics of various NPs on several plant species are investigated through various reports, such as the reduce leaf growth and transpiration was observed in maize seedlings when cultivated in soil treated with $\mathrm{TiO}_{2}[20]$.

Table 1: Harmful role of nanoparticles on plant growth and physiology.

\begin{tabular}{|c|c|c|c|}
\hline Plant & Nanoparticles & Function & References \\
\hline Zea mays & $\mathrm{Al}_{2} \mathrm{O}_{3}$ & Inhibition of root elongation & Yeduction in shoot weight and length \\
\hline Oryza sativa & $\mathrm{CuO}$ & Decrease rate of growth and development & Shaw et al. 2013. \\
\hline Cucumis sativus & $\mathrm{CuO}$ & $\begin{array}{c}\text { Reduction in number of hydrogen bonds between water } \\
\text { and DNA nucleobase }\end{array}$ \\
\hline Oryza sativa & SWCNTs & Inhibition of seed germination \\
\hline Lepidium sativum & CNTS & Katti et al. 2015. \\
\hline
\end{tabular}

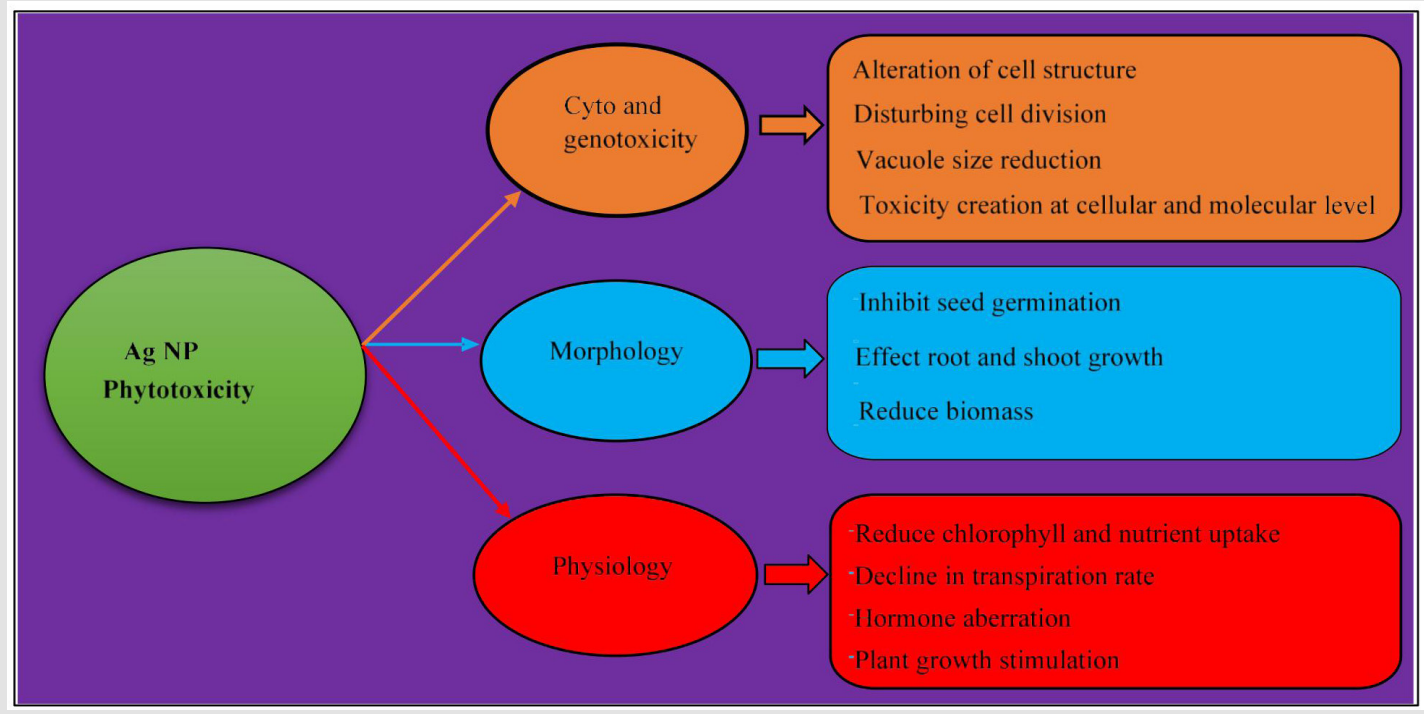

Figure 1: Role of Ag NPs in cytotoxicity and genotoxicity, morphology, and physiology of plants. 
$\mathrm{CuO}$ NP is preferred by the researcher more than NPs for medical usages owing to its biocidal and antibacterial characteristics [23-25]. Eminent toxic effects with durable existence after $72 \mathrm{~h}$ of the treatment is shown by $\mathrm{Cu}$ NPs when incorporated in algae contradictory to its bulk [26]. Mung bean and wheat when cultivated on agar with $\mathrm{Cu}$ NPs, resulted in decreased shoot dry matter and seedling length enhancement [27]. Figure 1. Hydroponically grown cucumber plants show a substantial upsurge in the production of ROS, enzyme peroxidase (POD), catalase (CAT) and super dismutase (SOD) that further enhances the phytotoxic effect of Cu NP [28-30]. Figure 2.

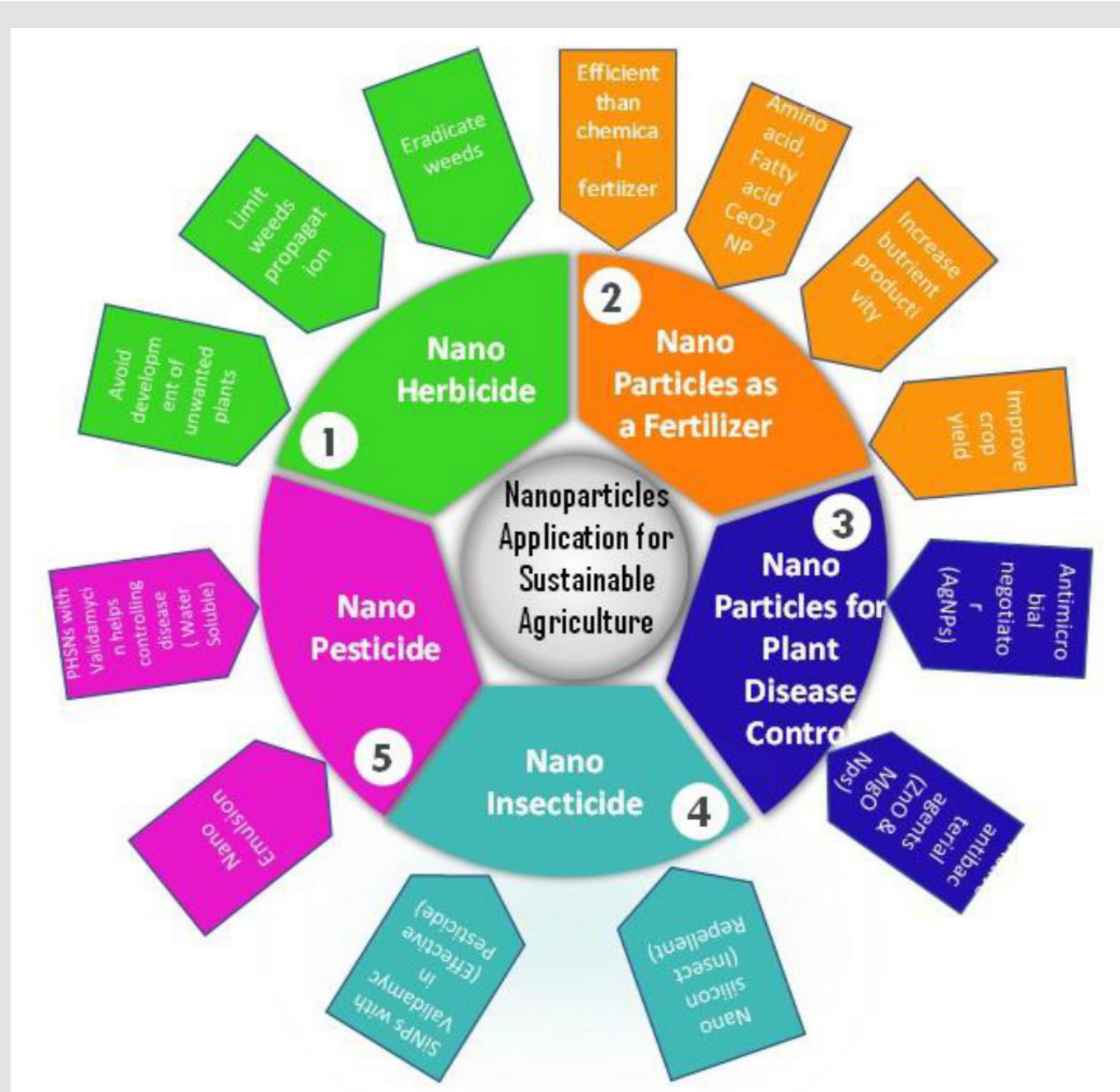

Figure 2: Application of nanoparticles in the areas of herbicides, fertilizers, disease control, insecticide, and pesticide for sustainable agriculture.

\section{Beneficial Aspects of Nanoparticles, their Instigated Phytotoxicity and Harmful Effects on the Environment}

Being a novel science, nanotechnology is an uppermost trending field in the scientific society owing to the vast utilizations and employments of nanoparticles (NPs) in numerous research areas and industries. NPs have been employed in diverse fields like cosmetics, electronics, and medicine [31-35]. There are vulnerable queries on environmental effects of NPs that are extensively used in daily life, regardless of the evident gains offered by NPs. During disposal, utilization and production, NPs are excessively liberated into the environment due to their broad use [36-39]. Escalated concentrations of NPs create detrimental impacts on living things counting plants [40-42]. Phytotoxicity pose harms to the health of humans via food chain afterwards [43]. There is not much inclusive knowledge in spite of various research displaying phytotoxicity in plants by NPs [44-47]. NPs having both useful and harmful bearings on the plants have been described. For instance, peas demonstrated stimulated growth of roots in contrast to control plants when applied with $\mathrm{Zn}_{0} \mathrm{NP}[48,49]$. $\mathrm{TiO}_{2}$ and $\mathrm{SiO}_{2}$ augmented the fertilizer nutrient and water absorbance in soybean (Glycine max) through enhancing the activity of nitrate reductase which influence antioxidant system [50] Figure 3. Spinach growth has been exhibited to enhance by increased nitrogen metabolism and photosynthesis using a specific amount of $\mathrm{TiO}_{2} \mathrm{NP}$ [51]. On the 
contrary, treatment with powders of nanoscale alumina (nano$\mathrm{Al}_{2} \mathrm{O}_{3}$ ) caused impediment of root enlargement in carrot, cucumber, cabbage, and corn [52-54]. Treatment of corn seedlings with $\mathrm{TiO}_{2}$ NP demonstrated lowered growth of leaves and transpiration rate
[55-57]. Mung bean and wheat plants cultivated on agar plates were used to analyze phytotoxicity caused by CuNP. They were found to diminish the growth rate of shoot and seedling [58].

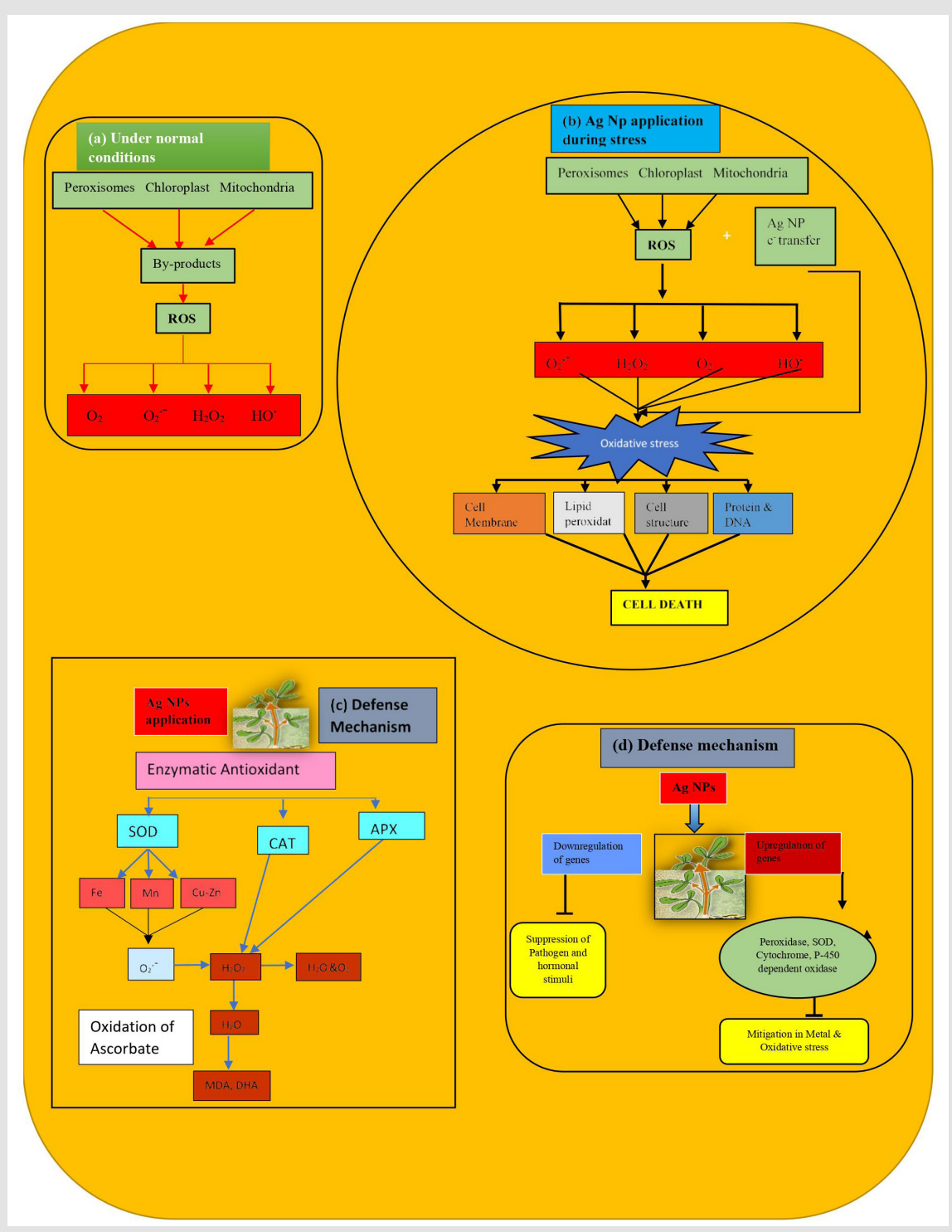

Note: $\left(\mathrm{O}_{2}\right.$ : singlet oxygen, $\left(\mathrm{O}_{2}\right.$-. $^{-}$: superoxide, $\mathrm{H}_{2} \mathrm{O}_{2}$ : hydrogen peroxide, (HO.): hydroxyl radical, (SOD): superoxide dismutase, (CAT): catalase, (APX): ascorbate peroxidase, (MDA) monodehydroascorbate, (DHA) dehydroascorbate).

Figure 3: Signaling crosstalk of Ag NPs application in plants.

a) Under normal environments peroxisomes, chloroplasts and mitochondria generate byproducts which produce ROS including Single oxygen, superoxide, hydrogen peroxide and hydroxyl radical.

b) Under stress environment oxidative stress is created in plant cells treated with Ag NPs. Huge damage is inflicted by the generation of ROS principally by transferring electron that results in cell death.

c) Plant utilizes its defense mechanism to elude the generation of ROS. When plants are treated with Ag NPs, enzymatic antioxidants SOD, CAT and APX are stimulated and safeguard plants from oxidative stress. SOD give $\mathrm{Fe}, \mathrm{Mn}$ and $\mathrm{Cu}-\mathrm{Zn}$ that modify the deleterious $\mathrm{O}_{2}$ - into a less harmful $\mathrm{H}_{2} \mathrm{O}_{2}$. CAT convert $\mathrm{H}_{2} \mathrm{O}_{2}$ in $\mathrm{H}_{2} \mathrm{O}$ and $\mathrm{O}_{2}$. APX convert $\mathrm{H}_{2} \mathrm{O}_{2}$ in water ( $\mathrm{H} 2 \mathrm{O}$ ) by oxidizing ascorbate into MDA and DHA. d) When Ag NPs are applied in Arabidopsis, it results in gene upregulation that elevate the expression of genes coding for Peroxidase, SOD, Cytochrome, P-450 dependent oxidase and eventually diminish the metal and oxidative stress. Conversely, applying Ag NPs also result in gene downregulation and diminish gene expression levels of those genes that assist in pathogenic and hormonals stimuli. 
Although CuNP have numerous usages, they may also confer undesirable effects to the environment. Largely, the harmfulness of the NPs is determined by $\mathrm{pH}$, surface charge and size of the environment [59]. Moreover, Kim described the phytotoxic influence on hydroponically cultivated plants of cucumber treated with CuONP with a $50 \mathrm{~nm}$ size. The plants displayed a prolific enhancement in ROS enzymes; superoxide dismutase (SOD), peroxidase (POD), and catalase (CAT) [60] Figure 2. In different research, CuONP considerably lessened the development and growth of plants of cucumber grown on soil-plant microcosm [61] Table 1. While earlier studies suggested that supplementary investigation is necessitated to study the CuNP phytotoxicity on various plants.

\section{Favorable and Unfavorable Attributes of Silver Nanoparticles, their Transport and Accretion in Arabidopsis Thaliana}

Nowadays, there are several products of nanotechnologies that are available in market. Their large availability and usage in commercial market products raises alarms about their significant influence on health of humans, animals, and ecosystems. As these products are engineered, their health results have significantly been observed in wastewater and it has also been noticed that these particles are released from some products [62]. Engineered nanoparticles vary in size form 1-100 $\mathrm{nm}$ and they are pollutants which exhibit ambitious physio-chemical properties e.g., large surface area and confinement of surface [63]. Ambitious physiochemical attributes of engineered nanoparticles might result in varying environmental noxiousness and behaviors [64-66] Toxicity of engineered nanoparticles depend upon surface confinement and thus can be lowered by altering functions of surface. Dissolution plays role in altering determination of toxic engineered nanoparticles in case of metal nanoparticles. Plant specific toxicity of $\mathrm{TiO}_{2}$ nanoparticles in seedling of maize was due to lowered hydraulic conductivity which result from obstruction in pores of root cell walls [67]. In case of metallic nanoparticles, there are no cases of attempts being made to discriminate metallic nanoparticles present on tissues of plants. Of all the nanoparticles, silver nanoparticles are usually used in industries such as fabrics, food, medical dressing etc. as silver nanoparticles consist of some properties that are antimicrobial in nature [68]. Some silver nanoparticles that are used in environmental case studies are monovalent silver $\left(\mathrm{Ag}^{+}\right)$and elemental silver (AgO) [69]. It was assumed that monovalent silver was the source of silver toxicity, but the results were indecisive. Toxicity caused by silver nanoparticles have been researched thoroughly in animals [70-76]. However, very less is known about toxicity caused by silver nanoparticles in plants [77]. As plant are sessile in nature, their roots absorb not only water and nutrients but also pollutants and contaminants from an ecosystem.
Therefore, questions arise in mind that how silver nanoparticles will be transported in root system and can they be harmful to plants in turn causing damage to humans and animals as these are the last consumers of plant and derivative products. Silver nanoparticles exhibited phytotoxicity in Lemna paucicostata and Lolium multiflorum [78-80]. Copper nanoparticles are observed to cause phytotoxicity in bean and wheat [81], whereas zinc oxide nanoparticles were found attached to surface od root and their transportation in plant body was not observed [82]. Arabidopsis thaliana is a plant which has a very short life cycle i.e., 6-8 weeks and is considered a long day flowering plant, therefore, its small size makes it more feasible for study. Genome size of Arabidopsis is very small and consist of 157 mega base pairs [83-86]. When genome of Arabidopsis was developed in year 2000 in program Initiative 2000 [87], it has been studied by various scientist for research in plant biology [88].

The Arabidopsis Information Resource was founded in year 2001 [89]. The benefit of studying Arabidopsis is that its findings can be practiced in many other crops that may also have a different or bigger size of genome e.g., soybean which has a genome of 100 megabase [90-92], maize which size of genome is 2500 mega base [93] and can also be practiced in plants whose genomic data is not available e.g., cucumber. Arabidopsis life cycle is finely studied and characterized, and its reproductive and vegetative stages are well known [94]. Due to these benefits, Arabidopsis is usually used to study the influence of nanoparticles [95]. Therefore, to determine the influence of silver nanoparticles on the plants and plant derived products, more research is required on transportation of silver nanoparticles in biomass of plants and on regulation of genes [96].

\section{Impact of Various Nanomaterials on the Seedling Growth and Germinations of Seeds}

Currently, huge development in the discipline of Nanotechnology and Nanoscience was observed which allows us to develop engineered nanoparticles having different shapes, forms, and sizes [97]. As nanoparticles were using on huge scale, an interesting connection between agriculture and engineered nanoparticles was created which is quite striking by using them as a source of fertilizer and to cope with environmental hazards as well as for vibrant agriculture [98-100]. Modern study on nanoparticles indicates that plant shows different physiological responses during germination due to ENPs but considerable variations between nanoparticles and plants were reported which effect root growth and seed germination capability. For instance, in order to increase seed germination in fennel $\mathrm{TiO}_{2}$ nanoparticles will be deployed [101]. If 400 and $1600 \mathrm{mg} \mathrm{L}-1$ of nanoparticles of $\mathrm{ZnO}$ is used it will boost up the germination level of cucumber [102-105]. T able 1. According to Lahiani et al states that soybean, barley, and maize germination could be enhanced by using MWCNTs [106] Table 2. 
While on the contrary shoot weight, seeds germination and shoot length of rice is decreased by using CuO NPs [107] Figure 1, in mud Lepidium sativum seed germination would also been inhibited by using CNTs Table 1, Pennisetum glaucum germination efficiency is increased by using Ag NPs [108] Table 2. In contrast to this, modern study stated that NPs effect plant's growth but does not influence the germination. E.g., number of wheat roots will by decreased by using graphene as it does not influence seeds germination in wheat [109]. Root elongation of maize was inhibited by using $\mathrm{CuO}$ nanoparticles although it does not influence seed's germination of maize [110].

Table 2: Beneficial effects of nanoparticles on plant physiology and growth.

\begin{tabular}{|c|c|c|c|c|c|}
\hline Plant & Nanoparticles & Application Method & Concentrations & Results & References \\
\hline Pisum sativum & $\mathrm{TiO} 2$ & $\begin{array}{l}\text { Foliar treatment and } \\
\text { seed priming }\end{array}$ & 0.25 percent & $\begin{array}{l}\text { Elevated biomass accumulation, } \\
\text { protein chlorophyll, and nitrogen } \\
\text { concentrations }\end{array}$ & Yang et al. 2006 \\
\hline Pennisetum glaucum & Ag NPs & Seed treatment & $20,50 \mathrm{mg} / \mathrm{L}$ & Enhancement in seed germination & Parveen et al. 2015 \\
\hline Cucumis sativus & $\mathrm{ZnO}$ & Seed treatment & $400-1600 \mathrm{mg} / \mathrm{L}$ & Increased germination by $10 \%$ & Rosa et al. 2013 \\
\hline Solanum lycopersicum & MgO & Soaking & $7-10 \mu \mathrm{g} / \mathrm{mL}$ & $\begin{array}{c}\text { Tolerance against bacterial wilt } \\
\text { infection }\end{array}$ & Imada et al. 2016 \\
\hline
\end{tabular}

Note: (MWCNTs: Multi-walled carbon nanotubes)

\section{Role of $\mathrm{C}_{60}$ Fullerenes and Multi-Walled Carbon Nanotubes in Plants}

The domain of nanotechnology is flourishing continuously. It is assessed that the market value of nanotechnology would probably exceed $\$ 3000000$ in 2020 [111]. One of the main reasons of this upturn is gaining knowledge about inimitable physical and chemical properties at nanometer scale which allow us to make enquiries, increase development and improve their application by drawing a line between nanometer scales and their bulk products efficiently. Of the total commercially accessible products like cosmetics, plastics, surgical instruments, and fabrics engineered nanomaterials were using most commonly [112]. As engineered nanomaterials were being used on a significantly large scale as well as due to their improved usage it is certain to release them in the environment. But still scientific community agree upon this fact that we are still short of information about nanomaterial especially its effects on the environment which leads to the development of econanotoxicology and nanotoxicology domains as we are unbale to build a framework which monitor risk or toxicity related concern in the ultimate onsumer's product [113-116]. For food processing or production and in agriculture, engineered nanoparticles were using which is prominent problem. Engineered NPs were developed in agriculture to

(i) Generate minimum waste

(ii) Water and energy will be saved in sufficient amount as agricultural products will give us high yield and available to us before its actual maturity.

Main objective of this technique is to present cheap, well- organized, sustainable, and benign agricultural practices [117].

We are still facing short of information about nanomaterials used in agricultural system especially their outcomes as their use causes contamination in food chain and influenced the human health in varieties of ways [118-120]. Inorganic nanostructure does not reach the level of carbon nanomaterial, one of the main reasons is that we can easily produce them as well as bring changes due to their distinctive chemical and physical properties [121]. According to Miralles et al if we want to improve germination and roots elongation of alfalfa and wheat MWCNTs will be very helpful, but the problem arises during uptake and transfer of MWCNTs to different parts [122]. For appropriate plant growth and cell division genes expression play a very crucial role, therefore Khodakovskaya and his colleagues studied and comes to know exactly the same thing and also defined that MWCNTs have the potential to escalate the growth rate in tomato plants and tobacco cells [123]. Nonetheless, many researchers illustrated that for numerous plant species carbon nanomaterials are injurious [124-126]. Common relationship between inorganic modification, organic chemicals and engineered nanomaterials in agricultural system is still hidden. Carbon nanomaterials have an ability to make a strong bond with inorganic and organic substances owing to their hydrophobic nature and big surface area [127-130]. The probable relationship can be complicated it may limit efficiency of pesticides which give rise to economic issue, or it may increase contaminants accumulation which yield in food safety issues. In cottonwood $82 \%$ increase in trichloroethylene uptake was observed by Ma and Wang by applying $C_{60}$ [131]. Kelsey and White discovered that $C_{60}$ exposure had negligible influence on the weathered DDE accretion in the soil by earthworm and pumpkin [132]. 


\section{Deploying Nanotechnology for Elevating the Levels of Plant Growth and Crop Protection}

Currently, beneficial, and important inventions are introduced in agriculture so that enhancing difficulties related to food security and production via sustainable means can be overcome [133138]. With escalating population of the world excessive food is required, these innovations are pivotal elements in achieving this by utilizing various other resources simultaneously such as synthetic and natural resources. As there are several problems emerging in the field of agriculture the only solution for these problems in general is, nanotechnology. Researchers are interested in utilizing nanotechnology for diminishing the rift in molecular or atomic structures and material with huge size. Important research related to nanotechnology are conducted to highlight its use in agriculture in past twenty years [139-141]. To enhance the production of various crops, fruits and vegetables fertilizer played a significant role, but in-addition to the benefits there are some lethal disadvantages of using fertilizers extravagantly. When used excessively fertilizers decreases the availability of good land for producing crops by amending the chemical nature of soil. As less agrochemical use-age is the demand of Sustainable agriculture therefore it is mostly preferred for securing various species which are about too extinct and to save environment [142]. The capability of Agri-inputs to help regulate the site aimed nutrient availability is enhanced remarkably by reducing the agriculture input i.e., utilizing nanotechnology for achieving a striking production of crops.

Enhanced crop production and excessive plant protection is now attainable certainly because of the aid provided by nanotechnology. As the major constrain in crop production is climate change and the fragility of ecosystem so to overcome these problems, we have to adopt nanotechnology enabling the plants to excessively adapt the continuous changes in water content, alkalinity, temperature, salinity, and the accumulation of toxic metals causing environmental pollution [143]. Moreover, the human command on health of plant and soil is maintainable only by introducing precision farming which is made possible sable only by utilizing and devising nano sensors. These nano sensors are used for examining the soil conditions, environmental pollution, seepage of agrochemicals, various diseases Figure 3 and for measuring the crop growth [144]. A wider specific area which is significant for maintainable development of agricultural system is attainable by nano-material engineering which is the modern research track as it is assist the innovation of agriculture fields with advanced technology is. Modern industrial agriculture is facing various problems and the only solution to them is nanotechnological inventions related to agriculture which can diminish these obstacles by introducing diminutive technological fixes [145]. Hence nanotechnology is the only replacement we have against the orthodox technologies for coordinating the strategies of management as well as for diminishing the ambiguities.

\section{Plant Growth Amelioration Using Carbon Nanotubes}

It is noteworthy that low dosage of specific nanomaterials stimulates physiological processes in plants. In case of spinach, an optimum concentration of $\mathrm{TiO}_{2}$ nanoparticles augmented the plant growth by effecting rate of photosynthesis [146]. In ryegrass [147] and onion, cucumber [148] the root growth was boosted by carbon nanotubes. Multiwalled carbon nanotubes (MWCNTs) are showed to stimulate the gene expression which are crucial for the cell division and plant development [149-150] and ameliorate the growth in tomato [151]. Conversely, single walled nanotubes (SWCNTs) have the ability to pierce the cell walls and plasma membranes in tobacco plants [152]. This piercing trait of NPs has incited curiosity in the expectation of using NPs delivery systems in plants [153]. DNA can be transmitted into plants by penetrating the cell walls by utilizing gold-capped mesoporous silica nanoparticles (MSNs) and exercising bombardment method [154]. Herbicides can be provided to the plants using nanocapsules. This practice is likely to provide increased penetration across the tissues of plant and allow measured and perpetual herbicidal release [154-156] Figure 3.

The use of nanoporous silica beside urease enzymes allow the better regulation of ammonia release from urea fertilizer [157] Figure 3. In another case, a plant growth regulator (NAA) is liberated precisely using zinc-aluminum-layered double- hydroxide nanocomposites [158]. Robust uptake and diffusion of carbon nanotubes has been exhibited using $C_{70}$ (fullerene) in rice [159]. Whereas some researchers found out that the carbon nanoparticle fullerene $\left(\mathrm{C}_{60}\right)$ had a minor influence on the functioning and anatomy of the microbial community in soil [160]. Growth of young tomato seedlings has been elevated by inducing single walled carbon and multi walled carbon nanotubes in a nanotube supplemented medium [161]. The tomato plants acquiring CNTs show more height and give double times the fruit and flower per plant in contrast to plants grown in controlled environment and procuring activated carbon [162]. Subjection of tomato seedlings to escalated negative surface charged, well-dispersed and efficient CNTs exhibited paramount increase in growth [163]. The tubular structured crystalline CNTs with surface thickness of only about 25 $\mathrm{nm}$ in contrast to relatively larger non-crystalline activated carbon materials may boost surplus uptake and synergy with biological system [164].

Root growth is boosted by carbon nanotubes (CNTs) as they enhance the global histone acetylation in meristem region in the roots of rice by modulating the related genes [165]. The cell walls in 
rice root contains multi-walled CNTs while Intercellular spaces in rice roots comprises of Single-walled CNTs (SWCNTs) [166]. SWNTs and MWCTs modulate various processes such as the photosynthetic rate and chlorophyll contents are enhanced by regulating the related gene as well as the development and leaf growth is modulated at a specified concentration of $20 \mathrm{mg} / \mathrm{L}$ [167]. The escalation of antioxidant enzyme activities and gibberellin content in addition with the reduction in abscisic acid both are performed by single walled and multiwalled CNTs [168]. In rice, the hydrogen bonds between DNA nucleobases and water are reduced by Singlewalled CNTs [169] Table 1. In contrast to the control, treatment with $500 \mathrm{mg} / \mathrm{kg} \mathrm{C60,} \mathrm{MWCNTs} \mathrm{and} \mathrm{rGo} \mathrm{extensively} \mathrm{escalates} \mathrm{the}$ concentrations of IAA, BR, and gibberellin acid 4 (GA4) in the roots of plant [170]. GO nanosheets hinders the growth of roots, contents of plant endogenous hormone and cell wall synthesis [171]. Several mechanisms depend on CNTs such as the cell interactions depends on different types of CNT related variables like impurities [172], size [173-175], functional group densities [176], duration of exposure [177] conjugated surfactant [178], and concentration [179]. In addition to the membrane hyper-polarization, apoptosis [177], oxidative stress [180], and aggregation of cells [181] is elicited by CNTs.

The visual image of nanomaterials in tissues and cells of plants the accurate delivery of chemicals and DNA into plants can be performed because the initiative work with NPs has facilitated the proficient DNA and chemicals transfer into the plants [182] and the visualization of nanomaterials in the tissues of plants [183] and cells [184]. However, there are several factors still to be appraised such as the risks of nanoparticles released into the environment incidentally. The protoplasts extracted from plant tissues have physiological activities identical to that of an infant cell as well as they maintain their cell differentiation and identity according to various studies [185]. To study several stress responses systems in plants for cell biology and genetic engineering, protoplast is used as a model system [186-188].

\section{Gene Delivery in Plants Via Mesoporous Silica Nanoparticles as Transporters}

The usage of nanomaterials in biological and medical research has acquired great curiosity lately. Several kinds of inorganic nanoparticles with distinctive chemical and physical characteristics, counting semiconductors, metals, metal oxides, silica, and carbonbased materials, are manufactured for transfer or tracking functions. Amongst these, mesoporous silica nanoparticles have acquired consideration recently $[189,190]$. MSNs have enriched textural properties, counting a large pore volume and surface area $(>1000$ $\left.\mathrm{m}^{2} \mathrm{~g}^{1}\right)$, tunable pore size $(2-20 \mathrm{~nm})$ and simply functionalized surfaces. MSNs usages have been exhibited in numerous biomedical fields, like protein and enzyme transfer [191-193], RNA or DNA transfection [194-196], in stimuli-responsive transfer of drug [197199], multi-practical theranostic agents [200] and cell markers for bioimaging (MRI and fluorescence) [201]. The reaction of living targets to MSNs counting biocompatibility, biodegradability and cytotoxicity have been researched in mammal cells.

Conversely, in plant sciences, cell walls of plants inhibit the usage of nanoparticles contrasting the mammalian system. Presently, greater proportion of research emphasize over the phytotoxicity caused by nanoparticles [201-203] and the impact of nanoparticles on the plant development. In plant sciences, regardless of inadequate research, it has been narrated that cell of plant may uptake extremely little nanoparticles, amid them being $\mathrm{CdSe} / \mathrm{ZnS}$ quantum dots, single and multi-walled carbon nanoparticles, carbon-coated magnetic nanoparticles and anatase $\mathrm{TiO}_{2}$ alizarin red $\mathrm{S}$ nanoconjugates. The tiny nanoparticles reach the cells via different modes in plants, like making new pores, ion channels, attaching to a carrier protein etc [200]. However, it has been displayed that the devoured nanoparticles might function as transport vehicles for the whole plant according to some studies. There are a small number of research demonstrating the nanoparticles-mediated transfer of biomolecules into the plant cells [194-200].

Cells of plants that lack a cell wall are referred to as protoplasts and thereby nanoparticles macromolecules can be engulfed using endocytosis. Unluckily, many of the studies utilized suspension of culture cells as objects exclusive of subsequent investigation of the usage of differentiated tissues. Conversely, the separation of protoplast is a laborious method, and it is complicated to develop transmuted protoplasts and cultured cells into the whole plants. Mechanical forces, like ultrasound or biolistic method are the main basis of present practices counting nanoparticles for piercing the cell wall obstructions for transferring biomolecules into plants. An ultrasonic method is principally deployed for culture cells, nonetheless, it is uncomplicated to operate and less costly. Lately, by utilizing the gene gun method, gold-capped MSNs are displayed to transport chemicals, protein, and DNA to the cultured or extracted cells. Still, nanoparticles coated with the biomolecules just aim at the plant surface tissues and bombardment method is relatively expensive. The lower activity rate of endocytosis and impediment of cell walls constrains the usage of nanomaterials in plant cells. A biomolecule transferring method using nanoparticles could assist plant biotechnology exponentially, as a method like this endows a less costly and uncomplicated procedure to attain many resolutions in high throughput research, particularly after these nanomaterials penetrate the whole plants suddenly.

However, till now, merely calcium phosphate and poly dendrimer nanoparticles have demonstrated that these nanoparticles can be procured into the cells of plants through uncomplicated 
culture techniques, and they function as transporters without any additional assistance for transferring genes except for cell-piercing peptides, of non- nanomaterial-based particles [203]. Yet, according to these findings, the process of nanoparticles uptake, impact of the nanomaterials on the target cells following the uptake, and the subcellular dissemination of nanomaterials inside the cells were not directed.

\section{Usages of Nanotechnology in Crop Protection and Growth}

Currently, beneficial, and important inventions are introduced in agriculture so that enhancing difficulties related to food security and production via sustainable means can be overcome. With escalating population of the world excessive food is required, these innovations are pivotal elements in achieving this by utilizing various other resources simultaneously such as synthetic and natural resources. As there are several problems emerging in the field of agriculture the only solution for these problems in general is nanotechnology. Researchers are interested in utilizing nanotechnology for diminishing the rift in molecular or atomic structures and material with huge size. Important research related to nanotechnology are conducted to highlight its use in agriculture in past twenty years. To enhance the production of various crops, fruits and vegetables fertilizer played a significant role, but inaddition to the benefits there are some lethal disadvantages of using fertilizers extravagantly. When used excessively fertilizers decreases the availability of good land for producing crops by amending the chemical nature of soil. As less agrochemical useage is the demand of Sustainable agriculture therefore it is mostly preferred for securing various species which are about too extinct and to save environment. The capability of Agri-inputs to help regulate the site aimed nutrient availability is enhanced remarkably by reducing the agriculture input i.e., utilizing nanotechnology for achieving a striking production of crops.

Enhanced crop production and excessive plant protection is now attainable certainly because of the aid provided by nanotechnology. As the major constrain in crop production is climate change and the fragility of ecosystem so to overcome these problems, we must adopt nanotechnology enabling the plants to excessively adapt the continuous changes in water content, alkalinity, temperature, salinity, and the accumulation of toxic metals causing environmental pollution. Moreover, the human command on health of plant and soil is maintainable only by introducing precision farming which is made possible sable only by utilizing and devising nano-sensors. These nano-sensors are used for examining the soil conditions, environmental pollution, seepage of agrochemicals, various diseases and for measuring the crop growth. A wider specific area which is significant for maintainable development of agricultural system is attainable by nano- material engineering which is the modern research track as it assists in the innovation of agriculture fields with advanced technology. Modern industrial agriculture is facing various problems and the only solution to them is nanotechnological inventions related to agriculture which can diminish these obstacles by introducing diminutive technological fixes. Hence nanotechnology is the only replacement we have against the orthodox technologies for coordinating the strategies of management as well as for diminishing the ambiguities.

\section{Transport and Translocation of Fluorescently Labeled Mesoporous Silica Nanomaterials in Plants}

Nanotechnology is a fast-developing area and usages of nanomaterials in medicinal and biotic examination has involved numerous investigation collections to target vital investigation matters like addressed tissue engineering, diagnostics, drug delivery and ecological remediation. There exist diverse kinds of mineral NPs through exceptional structures, as well as metaled, metallic oxides, silica, semiconductors, and carbon-based resources testified for distribution and chasing purposes. Between these, mesoporous silica nanoparticles (MSNs) have influenced as a prolific biomolecule distribution automobile in the systems of mammals e.g., mesoporous silica nanoparticles (MSNs) attained consideration for the usages in carrier vehicles, particularly in animals, where they are used in drug delivery for treating cancer [191]. MSNs are procured into acidic lysosomes of the cells by utilizing endocytosis. They are harmless to the living cells, which makes them a prevailing drug transport aspirant [193]. Furthermore, MSN pores are capped by compatible molecular porters to ensure that an internalized carriage can efficiently extend to the particular target. Amid the porter's reaction to external or internal stimulus, a perpetual and regulated release structure is attained like initiation of light, changes in temperature and $\mathrm{pH}$, competitive binding, and activation of redox.

The knowhow and usages of MSNs on quantification, sub-cellular localization and uptake mechanism in the plants are narrated sporadically as compared to numerous findings on the uptake pathways and their appliances as a bio-molecule transport cargo in mammalians. Numerous non-porous NPs have been validated for their uptake and noxiousness together in mammalians and plants, however, they are less versatile in contrast to MSNs. The greater proportion of experiments were conducted on protoplasts without call walls, calli and extracted cells cultured in fluid suspension. Conversely, Chang and his associates demonstrated transport of DNA into the endodermis and cortical cells of the roots of Arabidopsis thaliana utilizing $100 \mathrm{~nm}$ MSNs, however, in the midair plant parts, no validation of expression of genes was described [197]. MSNs own many distinctive traits which make them suitable biomolecule vehicles for tiny molecules. These include lower degradability and elevated biocompatibility under physiological environments, luxury of surface functionalization, high surface 
area, big volume of tunable pores, chemical and physical stability Scarcity of information of these nanoparticles concerning transport and translocation within the plants has confined the potential to exploit the distinctive characteristics of MSNs as a transport vehicle in plants. Protoplasts and plants grown in-vitro were regarded as an excellent standard system for examining and grasping the transport of MSNs operationalized with DNA and proteins before running trials for assessing extensive distance MSNs delivery, as demonstrated persuasively by various studies.

The cells deprived of cell walls are referred to as protoplasts and therefore biomolecules, like nanoparticles, might be procured by the cells through endocytosis. Though, altered culture cells and protoplasts of suspension are challenging to regrow into whole plants and the protoplast extraction is a wearying procedure. Mechanical forces, like ultrasound or biolistic method are the main basis of current practices involving nanoparticles for piercing the cell wall impediments for transporting biomolecules into plants An ultrasonic method is basically employed for culture cells, however, it simpler to operate and less costly. Lately, by using the biolistic method, gold-capped MSNs are exhibited to transfer chemicals, protein, and DNA to the cultured or extracted cells [201-203]. In spite of that, nanomaterials coated with the biomolecules purely aim at the plant surface tissues and bombardment method is expensive.

\section{Conclusion and Future Prospects}

For many years, non-artificial nanomaterials have occurred in the environment, and they produce fewer toxic effects among plants, humans, and animals. Lately, the determination of toxicity caused by NPs in plants is an extremely necessitated research discipline all over the world. Nanoparticles facilitate the enhancement of growth and development in plants. Though, some recent findings have unveiled a few harmful properties of nanoparticles in living organisms. From this review paper, it is noticeable that engineered NPs are capable to bring about hazardous effects in the living systems and environment. In several countries, laws and regulations have been issued to evade or reduce the potential jeopardizes of engineered nanoparticles. Wider studies are imperative in the discipline of nanotechnology to recognize and evade hazardous nanoparticles. Furthermore, emergent nanomaterials ought to be put to thorough toxicity testing. Biosynthesized nanoparticles are preferable for usage. We can ascertain their phytotoxicity levels through regulating their concentration and size. Nanoparticles have exponential capability to ameliorate development and growth in plants in the future through escalating photosynthetic activity, augmenting uptake of water and nutrients. Though, there is a necessity to augment the use of nanomaterials in agriculture through evolving target-specific and environment friendly nanoparticles to enhance physical parameters, growth of plants without harming the environment.

\section{References}

1. Andrew D Maynard, D B W, Martin A, Philbert (2010) The New Toxicology of Sophisticated 464 Materials: Nanotoxicology and Beyond. Toxicological Science 120(S1): S109-S129.

2. Asli S, Neumann PM (2009) Colloidal suspensions of clay or titanium dioxide nanoparticles can inhibit leaf growth and transpiration via physical effects on root water transport. Plant Cell Environ 32(5): 577 584 .

3. Auffan M, Rose J, Bottero JY, Lowry GV, Jolivet JP, et al. (2009) Towards a definition of inorganic nanoparticles from an environmental, health and safety perspective. Nat Nanotechnol 4: 634-641.

4. Auffan M, Bottero JY, Chaneac C, Rose J (2010) Inorganic manufactured nanoparticles: how their physicochemical properties influence their biological effects in aqueous environments. Nanomedicine (Lond) 5(6): 999-1007.

5. Chugh E, Amundsen, F Eudes (2009) Translocation of cell-penetrating peptides and delivery of their cargoes in triticale microspores. Plant Cell Rep 28(5): 801-810.

6. AK Shaw, Z Hossain (2013) Impact of nano-CuO stress on rice (Oryza sativa L.) seedlings. Chemosphere 93(6): 906-915.

7. Parveen, S Rao (2015) Effect of Nanosilver on Seed Germination and Seedling Growth in Pennisetum glaucum. J Clust Sci 26: 693-701.

8. Perez-de-Luque, D Rubiales (2009) Nanotechnology for parasitic plant control. Pest Manag Sci 65(5): 540-545.

9. T Silva, N Alien, C M Ye, J Verchot, J H Moon (2010) Conjugated polymer nanoparticles for effective siRNA delivery to tobacco BY-2 protoplasts. BMC Plant Biol 10.

A. Ziemienowicz YS, Shim A, Matsuoka F, Eudes, I Kovalchuk, et al. (2012) A Novel Method of Transgene Delivery into Triticale Plants Using the Agrobacterium Transferred DNA-Derived Nano-Complex ${ }^{[\mathrm{W}][\mathrm{OA}]}$. Plant Physiol 158(4): 1503-1513.

10. Baughman RH, Zakhidov AA, De Heer WA (2002) Carbon nanotubesthe route toward applications. Science 297(5582): 787-792.

11. Bennett, Leitch IJ, Price HJ, Johnston JS (2003) Comparisons with Caenorhabditis ( 100 Mb) and Drosophila $(\sim 175 \mathrm{Mb})$ Using Flow Cytometry Show Genome Size in Arabidopsis to be $\sim 157 \mathrm{Mb}$ and thus $\sim 25 \%$ Larger than the Arabidopsis Genome Initiative Estimate of $\sim 125$ Mb. Ann Bot 91(5): 547-557.

12. Benn TM, Cavanagh B, Hristovski K, Posner JD, Westerhoff P, et al. (2010) The release of nanosilver from consumer products used in the home. J Environ Qual 39(6): 1875-1882.

13. Bhatt I, Tripathi B N (2011) Interaction of engineered nanoparticles with various components of the environment and possible strategies for their risk assessment. Chemosphere 82(3): 308-317.

14. Bianco A, K Kostarelos, M Prato (2005) Applications of carbon nanotubes in drug delivery. Current Opinion in Chemical Biology 9(6): 674 -679.

15. Chang FP, Kuang LY, Huang CA, Jane WN, Hung Y, et al. (2013) A simple plant gene delivery system using mesoporous silica nanoparticles as carriers. J Mater Chem B 1: 5279-5287.

16. Chang YN, Zhang M, Xia L, Zhang J, Xing G, et al. (2012) The toxic effects and mechanisms of $\mathrm{CuO}$ and $\mathrm{ZnO}$ nanoparticles. Materials 5(12): 28502871. 
17. Chen R, Ratnikova TA, Stone MB, Lin S, Lard M, et al. (2010) 472 Differential uptake of carbon nanoparticles by plant and Mammalian cells. Small 6(5): 612-617.

18. Cheng Y, Yin L, Lin S, Wiesner M, Bernhardt E, et al. (2011) Toxicity reduction of polymer- stabilized silver nanoparticles by sunlight. J Phys Chem C 115(11): 4425-4432.

19. Christian P, Von der Kammer F, Baalousha M, Hofmann T (2008) Nanoparticles: structure, properties, preparation and behaviour in environmental media. Ecotoxicology 17(5): 326-343.

20. E Ashley, E C Carnes, KE Epler, D P Padilla, G K Phillips, et al. (2012) Delivery of Small Interfering RNA by Peptide-Targeted Mesoporous Silica Nanoparticle-Supported Lipid Bilayers. ACS Nano 6(3): 2174-2188.

21. H Lee, S H Cheng, I P Huang, J S Souris, C S Yang, et al. (2010) Int Ed 49: 8214-8219.

22. Colilla M, Gonzalez B, Vallet-Regi M (2013) Mesoporous silica nanoparticles for the design of smart delivery nanodevices. Biomater Sci 1: 114-134.

23. M Rico, S Majumdar, M Duarte-Gardea, J R Peralta- Videa, J L GardeaTorresdey, et al. (2011) Interaction of Nanoparticles with Edible Plants and Their Possible Implications in the Food Chain 59(8): 3485-3498.

24. Maurel (2007) Plant aquaporins: Novel functions and regulation properties. FEBS Lett 581(12): 2227.

25. W Lee, S Mahendra, K Zodrow, D Li, Y C Tsai, et al. (2010) Alvarez, Environ. Toxicol Chem 29: 669-675.

26. CW Lu, Y Hung, J K Hsiao, M Yao, T H Chung, et al. (2007) Nano Lett 7: 149-154.

27. Chen YW, Lee HV, Juan JC, Phang SM (2016) Production of new cellulose nanomaterial from red algae marine biomass Gelidium elegans. Carbohydr. Polym 151: 1210-1219.

28. De La Torre-Roche R, Hawthorne J, Deng Y, Xing B, Cai W, et al. (2012) Fullerene-enhanced accumulation of p,p'-DDE in agricultural crop species. Environ Sci 502 Technol 46(17): 9315-9323.

29. Dimkpa CO, McLean JE, Britt DW, Anderson AJ (2012) Bioactivity and Biomodification of $466 \mathrm{Ag}, \mathrm{ZnO}$, and $\mathrm{CuO}$ Nanoparticles with Relevance to Plant Performance in Agriculture. Industrial 467 Biotechnology 8(6): 14

30. Du J, Huang Y-P, Xi J, Cao M-J, Ni W-S, et al. (2008) Functional genemining for salt- tolerance genes with the power of Arabidopsis. Plant 56(4): 653-664.

31. Du W, Yang J, Peng Q Liang X, Mao H, et al. (2019) Comparison study of zinc nanoparticles and zinc sulphate on wheat growth: From toxicity and zinc biofortification. Chemosphere 227: 109-116.

32. H Lin, B S Xing (2007) Phytotoxicity of nanoparticles: inhibition of seed germination and root growth. Environ Pollut 150(2): 243-250.

33. L Slomberg (2012) MH Schoen sch, Environ Sci Technol 46: 10247 10254.

34. D Lin, B Xing (2007) Phytotoxicity of nanoparticles: inhibition of seed germination and root growth. Environ Pollut 150(2): 243-250.

35. DR Katti, A Sharma, SM Pradhan, KS Katti (2015) Carbon nanotube proximity influences rice DNA. Chem Phys 455: 17-22.

36. D W Pack, A S Hoffman, S Pun, P S Stayton (2005) Design and development of polymers for gene delivery. Nat Rev Drug Discovery 4(7): 581- 593

37. Dwivedi S, Saquib Q, Al-Khedhairy AA, Musarrat J (2016) Understanding the role of nanomaterials in agriculture. In Microbial Inoculants in Sustainable Agricultural Productivity. In: Singh DP, Singh HB, Prabha R (Eds.), Springer: New Delhi India, pp: 271-288.
38. Corredor, PS Testillano, M J Coronado, P Gonzalez- Melendi, R FernandezPacheco, et al. (2009) Nanoparticle penetration and transport in living pumpkin plants: in situsubcellular identification. BMC Plant Biol 9.

39. Etxeberria, P Gonzalez, E Baroja-Fernandez, J P Romero, Plant Signaling Behav et al. (2006) 1:196-200.

40.E M Mendenhall, K E Williamson, D Reyon, J Y Zou, O Ram, et al. (2013) Locus-specific editing of histone modifications at endogenous enhancers. Nat Biotechnol 31(12): 1133-1136.

41. Fan JP, Kalia P, Silvio Di, Huang J (2014) In vitro response of human osteoblasts to multistep sol- gel derived bioactive glass nanoparticles for bone tissue engineering. Mater Sci Eng C 36: 206-214.

42. Feazell RP, N Nakayama-Ratchford, HJ Dai, SJ Lippard (2007) Soluble single-walled carbon nanotubes as longboat delivery systems for platinum (IV) anticancer drug design. Journal of the American Chemical Society 129(7): 8438 - 8439.

43. A Ran, L Cong, W X Yan, D A Scott, J S Gootenberg, et al. (2015) In vivo genome editing using Staphylococcus aureus Cas9. Nature 520(7546): 186-191.

44. F Lu, S H Wu, Y Hung, C Y Mou, Small, et al. (2009) Size effect on cell uptake in well-suspended, uniform mesoporous silica nanoparticles 5(12): 1408-1413.

45. Torney, B G Trewyn, V S Y Lin, K Wang (2007) Mesoporous silica nanoparticles deliver DNA and chemicals into plants. Nat Nanotechnol 2(5): 295-300.

46. Gary-Bobo M, Hocine O, Brevet D, Maynadier M, Raehm L, et al. (2012) Cancer therapy improvement with mesoporous silica nanoparticles combining targeting, drug delivery and PDT. Int J Pharm 423(2): 509515 .

47. Grant D, Nelson RT, Cannon SB, Shoemaker RC (2010) SoyBase, the USDA-ARS soybean genetics and genomics database. Nucleic Acids Res 38: D843-D846.

48. De la Rosa, ML López-Moreno, D de Haro, CE Botez, JR Peralta-Videa, et al. (2013) Effects of ZnO nanoparticles in alfalfa, tomato, and cucumber at the germinationstage: Root development and X-ray absorption spectroscopy studies. Pure Appl Chem 85(12): 2161-2174.

49. M Pavan, L Albertazzi, A Danani (2010) J Phys Chem B 114: 2667-2675.

50. G Oberdörster, E Oberdörster, J Oberdörster (2005) Nanotoxicology: An Emerging Discipline Evolving from Studies of Ultrafine Particles. Health Perspect 133(7): 823-839.

51. Harris A, Bali R (2008) On the formation and extent of uptake of silver nanoparticles by live plants. J Nanopart Res 10(4): 691-695.

52. He P, L Shan, J Sheen (2006) The use of protoplasts to study innate immune responses. Plant - Pathogen Interactions 354: 1-10.

53. He X, Deng H, Hwang HM (2019) The current application of nanotechnology in food and agriculture. J Food Drug Anal 27(1): 1-21.

54. Hussain HI, Yi Z, Rookes JE, Kong LX, Cahill DM, et al. (2013) Mesoporous silica nanoparticles as a biomolecule delivery vehicle in plants. J Nanopart Res 15(6): 1-15.

55. Chung, Y Son, T K Yoon, S Kim, W Kim, et al. (2011) Ecotoxicol Environ Saf 74: 569 .

56. Feizi M, Kamali L, Jafari P (2013) Rezvani Moghaddam, Phytotoxicity and stimulatory impacts of nanosized and bulk titanium dioxide on fennel (Foeniculum vulgare Mill). Chemosphere 91(4): 506-511.

57. H Kim, J S Kim (2014) A guide to genome engineering with programmable nucleases. Nat Rev Genet 15(5): 321-334.

58. HL Tu, Y S Lin, H Y Lin, Y Hung, L W Lo, et al. (2009) Mesoporous silicananoparticles as nanocarriers. Adv Mater 21: 172-177. 
59. H Villagarcia, E Dervishi, K de Silva, A S Biris, M V Khodakovskaya, et al. (2012) Carbon Nanotubes Induce Growth Enhancement of Tobacco Cells. Small 6(3): 2328-2334.

60. H Yin, CQ Song, J R Dorkin, L J Zhu, Y Li, et al. (2016) Therapeutic genome editing by combined viral and non-viral delivery of CRISPR system components in vivo. Nat Biotechnol 34(3): 328-333.

61. H Yin, R L Kanasty, A A Eltoukhy, A J Vegas, J R Dorkin, et al. (2014) nonviral vectors for gene-based therapy. Nat Rev Genet 15(8): 541-555

62. H Zeng, HC Little, T N Tiambeng, G A Williams, Z Guan, et al. (2013) J Am Chem Soc 135: 4962-4965

63. H Zhu, J Han, J Q Xiao, Y Jin (2008) Uptake, translocation, and accumulation of manufactured iron oxide nanoparticles by pumpkin plants. J Environ Monit 10: 713.

64. H Zhang, M Yue, X Zheng, C Xie, H Zhou, et al. (2017) Physiological effects of single- and multi- walled carbon nanotubes on rice seedlings. IEEE Trans. Nanobiosci 16(7): 563-570.

65. (2000) Initiative TAG. Analysis of the genome sequence of the flowering plant Arabidopsis thaliana. Nature 408: 796-815.

66. I slowing, B G Trewyn, V S Y Lin (2007) Mesoporous Silica Nanoparticles for Intracellular Delivery of Membrane-Impermeable Proteins. J Am Chem Soc 129(28): 8845-8849.

67. ImadaK, SakaiS, KajiharaH, TanakaS, ItoS, et al. (2016) Magnesium oxide nanoparticles induce systemic resistance in tomato against bacterial wilt disease. Plant Pathol 65(4): 551-560.

68. Iqbal M, Raja NI, Hussain M, Ejaz M, Yasmeen F, et al. (2019) Effect of silver nanoparticles on growth of wheat under heat stress. IJST A Sci 43 387-395.

69. E Cañas, M Long, S Nations, R Vadan, L Dai, et al. (2008) Effects of functionalized and nonfunctionalized single-walled carbon nanotubes on root elongation of select crop species. Environ Toxicol Chem 27(9): 1922-1932.

70. Haensler, F C Szoka (1993) Bioconjugate Chem 4: 372-379.

71. Kurepa T, Paunesku S, Vogt H, Arora, B M Rabatic, et al. (2010) Uptake and distribution of ultrasmall anatase TiO2 Alizarin red S nanoconjugates in Arabidopsis thaliana. Smalle Nano Lett 10(7): 2296-2302.

72. J L Ferry, P Craig, C Hexel, P Sisco, R Frey, et al. (2009) Transfer of gold nanoparticles from the water column to the estuarine food web. Nat Nanotechnol 4(7): 441-444.

73. J Liu, F H Wang, L L Wang, S Y Xiao, C Y Tong, et al. (2008) J Cent South Univ Technol 15: 768-773.

74. J W Wiseman, C A Goddard, D McLelland, W H College (2003) Gene Ther 10: 1654- 1662 .

75. JYang, QZhang, H Chang, Y Cheng (2015) Surface-engineered dendrimers in gene delivery. Chem Rev 115(11): 5274-5300.

76. Kam, N W S, H J Dai (2005) Carbon nanotubes as intracellular protein transporters: Generality and biological functionality. Journal of the American Chemical Society 127(16): 6021-6026.

77. Kam, NW S, Z Liu, H J Dai (2006) Carbon nanotubes as intracellular transporters for proteins and DNA: An investigation of the uptake mechanism and pathway. Angewandte Chemie International Edition 45(4): $577-581$.

78. Kelsey, J W, White J C (2013) Effect of C60 fullerenes on the accumulation of weathered p, p'-DDE by 504 plant and earthworm species under single and multispecies conditions. Environ Toxicol Chem 32(5): 505(5): 1117-1123.
79. Khodakovskaya M V, De Silva K, Biris A S, Dervishi E, Hector Villagarcia (2012) Carbon nanotubes 481 induce growth enhancement of tobacco cells. ACS Nano 6(3): 2128-2135.

80. Khodakovskaya MV, De Silva K, Nedosekin DA, Dervishi E, Biris A S, et al. (2011) Complex genetic, photothermal, and photoacoustic analysis of 475 nanoparticle-plant interactions. Proc Natl Acad Sci USA 108(3): 1028-1033.

81. Khodakovskaya MV, Kim B S, Kim J N, Alimohammadi M, Dervishi E, et al. (2013) Carbon nanotubes as plant growth regulators: effects on tomato growth, reproductive 484 system, and soil microbial community. Small $9(1): 115-123$.

82. Kim E, Kim S-H, Kim H-C, Lee S, Lee S, et al. (2011) Growth inhibition of aquatic plant caused by silver and titanium oxide nanoparticles. Toxicol Environ Health Sci 3: 1-6.

83. Kim S, Lee S, Lee I (2012) Alteration of phytotoxicity and oxidant stress potential by metal oxide nanoparticles in Cucumis sativus. Water Air and Soil Pollut 223: 2799-2806.

84. Kim S, Sin H, Lee S, Lee I (2013) Influence of metal oxide particles on soil enzyme activity and bioaccumulation of two plants. J Microbiol Biotechnol 23(9): 1279-1286.

85. Kjemtrup S, Boyes DC, Christensen C, McCaskill AI, Hylton M, et al. (2003) Growth stage- based phenotypic profiling of plants. Methods Mol Biol 236: 427-442.

86. Koo H, Min KH, Lee SC, Park JH, Park K, (2013) Enhanced drug-loading and therapeutic efficacy of hydrotropic oligomer-conjugated glycol chitosan nanoparticles for tumor-targeted paclitaxel delivery. J Control Release 172(3): 823-831.

87. Koornneef M, Meinke D (2010) The development of Arabidopsis as a model plant. Plant J 61(6): 909- 921.

88. Kunzmann A, Andersson B, Vogt C, Feliu N, Ye F, et al. (2011) Efficient internalization of silica-coated iron oxide nanoparticles of different sizes by primary human macrophages and dendritic cells. Toxicol Appl Pharmacol 253(2): 81-93.

89. Kou TJ, Yu WW, Lam SK, Chen DL, Hou YP, et al. (2018) Differential root responses in two cultivars of winter wheat (Triticum aestivum L.) to elevated ozone concentration under fully open-air field conditions. J Agron Crop Sci 204: 325-332.

90.Z Hossain, C M Monreal, C M A Sayari (2008) Colloids Surf. B: Biointerfaces 62: 42.

91. Lahiani MH, Dervishi E, Chen JH, Nima Z, Gaume A, et al. (2013) Impact of carbon nanotube exposure to seeds of valuable crops. ACS Appl Mater Interfaces 5(16): 7965-7973.

92. Nyberg R F, Turco L Nies (2008) Environ Sci Technol 42: 1938.

93. LV Nhan, C Ma, Y Rui, S Liu, X Li, et al. (2015) Phytotoxic Mechanism of Nanoparticles: Destruction of Chloroplasts and Vascular Bundles and Alteration of Nutrient Absorption. Scientific Reports 5: 11618.

94. Lv M, Liu Y, Geng JH, Kou XH, Xin ZH, et al. (2018) Engineering nanomaterials-based biosensors for food safety detection. Biosens Bioelectron 106: 122-128.

95. Lee WM, An YJ, Yoon H, Kweon HS (2008) Toxicity and bioavailability of copper nanoparticles to the terrestrial plants mung bean (Phaseolus radiatus) and wheat (Triticum aestivum): plant agar test for waterinsoluble nanoparticles. Environ Toxicol Chem 27(9): 1915-1921.

96. Liepman AH, Wightman R, Geshi N, Turner SR, Scheller HV, et al. (2010) Arabidopsis - a powerful model system for plant cell wall research. Plant J 61(6): 1107-1121. 
97. Lin D, Xing B (2008) Root uptake and phytotoxicity of ZnO nanoparticles. Environ Sci Technol 42(15): 5580-5585.

98. Liu J, F H Wang, L L Wang, S Y Xiao, C Y Tong, et al. (2008) Preparation of fluorescence starch-nanoparticle and its application as plant transgenic vehicle. J Cent South Univ T 15: 768-773.

99. Liu Q L, B Chen, Q I Wang, X L Shi, Zeyu Xiao, et al. (2009) Carbon nanotubes as molecular transporters for walled plant cells. Nano Letters 9(3): 1007-1010.

100. Li X, Xie QR, Zhang J, Xia W, Gu H, et al. (2011) The packaging of siRNA within the mesoporous structure of silica nanoparticles. Biomaterials 32(35): 9546-9556.

101. Lu C, Zhang C, Wen J, Wu G, Tao M, et al. (2002) Research of the effect of nanometer materials on germination and growth enhancement of Glycine max and its mechanism. Soybean Sci 21(3): 168-171.

102. Lu J, Li Z, Zink JI, Tamanoi F (2012) In vivo tumor suppression efficacy of mesoporous silica nanoparticles-based drug-delivery system: enhanced efficacy by folate modification. Nanomed Nanotechnol Biol Med 8(2): 212-220.

103. An S R, Parkin, J E DeRouchey So Matter (2013) 10: 590-599.

104. MH Lahiani, E Dervishi, J Chen, Z Nima, A Gaume, et al. (2013) Impact of Carbon Nanotube Exposure to Seeds of Valuable Crops. ACS Applied Materials \& Interfaces 5(16): 7965-7973.

105. Khodakovskaya E, Dervishi M, Mahmood, Y Xu, Z R Li, et al. (2009) Carbon nanotubes are able to penetrate plant seed coat and dramatically affect seed germination and plant growth. ACS Nano3(10): 3221-3227.

106. Khodakovskaya K, De Silva, A S Biris, E Dervishi, H Villagarcia, et al. (2012) Carbon Nanotubes Induce Growth Enhancement of Tobacco Cells. ACS Nano 6(3): 2128-2135.

107. Khodakovskaya K, De Silva, D Nedosekin, E Dervishi, A S Biris, et al. (2011) PNAS 108: 1028.

108. M R Grimmer, S Stolzenburg, E Ford, R Lister, P Blancafort, et al. (2014) Nucleic Acids Res gku 708.

109. M Wang, Z A Glass, Q Xu (2016) Non-viral delivery of genome-editing nucleases for gene therapy. Gene Ther 24: 144-150.

110. M Z Hussein, Z Zulkarnain, A H J Yahaya, W V F Dickens (2002) J Control Release 82: 417.

111. Ma X, Geisler-Lee J, Yang D, Kolmakov A (2010) Interactions between engineered nanoparticles (ENPs) and plants: phytotoxicity, uptake and accumulation. Sci Total Environ 408(16): 3053-3061.

112. Ma Y, He X, Zhang P, Zhang Z, Guo Z, et al. (2011) Phytotoxicity and biotransformation of $\mathrm{La}_{2} \mathrm{O}_{3}$ nanoparticles in a terrestrial plant cucumber (Cucumis sativus). Nanotoxicology in press 5(4): 743-753.

113. Magrez A, S Kasas, V Salicio, N Pasquier, J W Seo, et al. (2006) Cellular toxicity of carbon-based nanomaterials. Nano Letters 6(6): 1121-1125.

114. Manna, S K S Sarkar, J Barr, K Wise, Enrique V Barrera, et al. (2005) Single-walled carbon nanotube induces oxidative stress and activates nuclear transcription factor- $\mathrm{k}$ B in human keratinocytes. Nano Letters 5(9): $1676-1684$.

115. Mariya V Khodakovskaya, Bong-Soo Kim, Jong Nam Kim, Mohammad Alimohammadi, Enkeleda Dervishi, et al. (2013) Carbon nanotubes as plant growth regulators: effects on tomato growth, reproductive system, and soil microbial community. small 9(1): 115-123.

116. Martin-Ortigosa S, PetersonDJ, Valenstein J S, LinVS-Y, TrewynBG, et al. (2014) Mesoporous silica nanoparticle mediated intracellular Cre protein delivery for maize genome editing via loxP sites excision. Plant Physiol 164(2): 534-547.

117. Martin-Ortigosa S, Valenstein JS, Lin VSY, Trewyn BG, Wang K, et al. (2012) Gold functionalized mesoporous silica nanoparticle mediated protein and DNA codelivery to plant cells via the biolistic method. Adv Funct Mater 22(17): 3576-3582.

118. Mauter M S, Elimelech M (2008) Environmental applications of carbonbased nanomaterials. 477 Environ Sci Technol 42(16): 5843-5859.

119. McCourt P, Benning C (2010) Arabidopsis: a rich harvest 10 years after completion of the genome sequence. Plant J 61(6): 905-908.

120. Mihail C Roco, C A M, Mark C Hersam (2011) Nanotechnology Research Directions for Societal 446 Needs in 2020: Retrospective and Outlook Summary. In Springer: New York.

121. Miralles P, Johnson E, Church T L, Harris A T (2012) Multiwalled carbon nanotubes in alfalfa and 479 wheats: toxicology and uptake. J R Soc Interface 9(77): 3514-3527.

122. Mota LC, Urena-Benavides EE, Yoon Y, Son A (2013) Quantitative detection of single walled 456 carbon nanotube in water using DNA and magnetic fluorescent spheres. Environ Sci Technol 47(1): 493-501.

123. Mukherjee A, Peralta-Videa J R, Bandyopadhyay S, Rico CM, Zhao L, et al. (2014) Physiological effects of nanoparticulate $\mathrm{ZnO}$ in green peas (Pisum sativum L.) cultivated in soil. Metallomics 6(1): 132-138.

124. Singh A Karambelkar, L Gu, K Lin, J S Miller, C S Chen, et al. (2011) Bioresponsive mesoporous silica nanoparticles for triggered drug release. J Am Chem Soc 133(49): 19582-19585.

125. Sozer, J L Kokini (2009) Nanotechnology and its applications in the food sector. Trends in Biotechnology 27(2): 82-89.

126. Nandiyanto ABD, Kim S-G, Iskandar F, Okuyama K (2009) Synthesis of spherical mesoporous silica nanoparticles with nanometer-size controllable pores and outer diameters. Microporous Mesoporous Mater 120(3): 447-453.

127. Nair R, Poulose AC, Nagaoka Y, Yoshida Y, Maekawa T, (2011) Uptake of FITC labeled silica nanoparticles and quantum dots by rice seedlings: effects on seed germination and their potential as biolabels for plants. J Fluoresc 21(6): 2057-2068.

128. Navarro DA, Bisson MA, Aga DS (2012) Investigating uptake of water dispersible CdSe/ZnS quantum dot nanoparticles by Arabidopsis thaliana plants. J Hazard Mater 211-212: 427-435.

129. Nicola, Bellucci, E Traversa, G D Bellis, F Micciulla, et al. (2008) Carbon nanotubes on Jurkat cells: Effects on cell viability and plasma membrane potential. Journal of Physics, Condense Matter 20: 474204.

130. Nowack B, Bucheli TD (2007) Occurrence, behavior and effects of nanoparticles in the environment. Environ Pollut 150(1): 5-22.

131. C Ray, H Yu, P P Fu (2009) Toxicity and environmental risks of nanomaterials: challenges and future needs. J Environ Sci Health C 27(1): 1-35.

132. Campeau P, Chapdelaine S, Seigneurin-Venin, B Massie, J Tremblay, et al. (2001) 8: 1387-1394.

133. Gonzales-Melendi, R Fernandez-Pacheco, M J Coronado, E Corredor, P S Testillano, et al. (2008) Ann Bot 101:187.

134. Gajjar B Pettee, D W Britt, W Huang, W P Johnson, A J Anderson, et al. (2009) Antimicrobial activities of commercial nanoparticles against an environmental soil microbe, Pseudomonas putida KT2440. J Biological Engin 3: 9.

135. Pacurari M, X J Yin, J S Zhao, M Ding, S S Leonard, et al. (2008) Raw single wall carbon nanotubes induce oxidative stress and activate MAPKs, AP-1, NF- $\mathrm{k}$ B, and Akt in normal and malignant human mesothelial cells. Environmental Health Perspectives 116(9): 1211-1217.

136. Panpatte DG, Jhala YK, Shelat HN, Vyas RV (2016) Nanoparticles: The next generation technology for sustainable agriculture. In Microbial Inoculants in Sustainable Agricultural Productivity; Springer: New Delhi India pp: 289-300. 
137. Peralta-Videa J R, Zhao L, Lopez-Moreno ML, de la Rosa G, Hong J, et al. (2011) Nanomaterials and the environment: a reviewforthebiennium2008-2010. J Hazard.Mater 186(1): 1-15.

138. Prasad R, Bhattacharyya A, Nguyen QD (2017) Nanotechnology in sustainable agriculture: Recent developments, challenges, and perspectives. Front Microbiol 8: 1014.

139. Popat A, Liu J, Hu Q Kennedy M, Peters B, et al. (2012) Adsorption and release of biocides with mesoporous silica nanoparticles. Nanoscale 4(3): 970-975.

140. J He, J L Shi, M Zhu, Y Chen, F Chen, et al. (2010) Microporous Mesoporous Mater 131: 314-320.

141. L Liu, Chen, Q L Wang, X L Shi, Z Y Xiao, et al. (2009) Carbon nanotubes as molecular transporters for walled plant cells. 9(3): 1007-1010.

142. Q O Wang, J N Chen, H Y Zhang, M Z Lu, D Y Qiu, et al. (2011) J Nanosci Nanotechnol 11: 2208-2214.

143. Q Zhou, X Hu (2017) Systemic stress, and recovery patterns of rice roots in response to graphene oxide nanosheets, Environ Sci Technol 51(4): 2022-2030.

144. Nair S H Varghese, B G Nair, T Maekawa, Y Yoshida, D S Kumar, et al. (2010) Nanoparticulate material delivery to plant. Plant Sci 179(2010): 154-163.

145. Q N Lin, Q Huang, C Y Li, C Y Bao, Z Z Liu, et al. (2010) Anticancer Drug Release from a Mesoporous Silica Based Nanophotocage Regulated by Either a One- or Two-Photon Process. J Am Chem Soc 132(31): 1064510647.

146. Liu, R Lal (2015) Potentials of engineered nanoparticles as fertilizers for increasing agronomic productions. Sci Total Environ 514: 131-139.

147. Radomski A, P Jurasz, D Alonso-Escolano, M Drews, M Morandi, et al. (2005) Nanoparticleinduced platelet aggregation and vascular thrombosis. British Journal of Pharmacology 146(6): 882 - 893.

148. Rhee SY, Beavis W, Berardini TZ, Chen G, Dixon D, et al. (2003) The Arabidopsis Information Resource (TAIR): a model organism database providing a centralized, curated gateway to Arabidopsis biology, research materials and community. Nucleic Acids Res 31(1): 224-228.

149. Rico C M, Majumdar S, Duarte-Gardea M, Peralta-Videa J R, GardeaTorresdey JL, et al. (2011) 469 Interaction of nanoparticles with edible plants and their possible implications in the food chain. J Agric 470 Food Chem 59(8): 3485-3498.

150. H Cheng, C C Hsieh, N T Chen, C H Chu, C M Huang, et al. (2011) Nano Today 6: 552-563.

151. H Wu, Y Hung, C Y Mou (2011) Mesoporous silicananoparticles as nanocarriers. Chem Commun 47(36): 9972-9985.

152. S Lin, J Reppert, Q Hu, J S Hudson, M L Reid, et al. (2009) Small 5: 1128.

153. S Martin-Ortigosa, J S Valenstein, W Sun, L Moeller, N Fang, et al. (2012) Small 8: 413-422.

154. S Martin-Ortigosa, J S Valenstein, V S Y Lin, B G Trewyn, K Wang, et al. (2012) Adv Funct Mater 22: 3576-3582.

155. S Naqvi, A N Maitra, M Z Abdin, M Akmal, I Arora, et al. (2012) Calcium phosphatenanoparticle mediated genetic transformation in plants. J Mater Chem 22(8): 3500-3507.

156. S Svenson, DA Tomalia (2012) Adv Drug Delivery Rev 64: 102-115.

157. S Yan, Z Hao, H Yan, J Tan (2016) Single-wall, and multi-wall carbon nanotubes promote rice root growth by eliciting the similar molecular pathways and epigenetic regulation. IET Nanobiotechnol 10(4): 222229.

158. Salata O V (2004) Applications of nanoparticles in biology and medicine. Journal of Nanobiotechnology 2: 3.
159. Schnable PS, Ware D, Fulton RS, Stein JC, Wei F, et al. (2009) The B73 Maize genome: complexity, diversity, and dynamics. Science 326(5956): 1112-1115.

160. Servin AD, Morales M I, Castillo-Michel H, Hernandez-Viezcas J A, Munoz B, et al. (2013) Synchrotron verification of $\mathrm{TiO}_{2}$ accumulation in cucumber fruit: a possible pathway of $\mathrm{TiO}_{2}$ nanoparticle transfer from soil into the food chain. Environ Sci Technol 47(20): 11592-11598.

161. Sheen J (2001) Signal transduction in maize and Arabidopsis mesophyll protoplasts. Plant Physiology 127: 1466 -1475.

162. Shultz JL, Kurunam D, Shopinski K, Iqbal MJ, Kazi S, et al. (2006) The Soybean Genome Database (SoyGD): a browser for display of duplicated, polyploid, regions and sequence tagged sites on the integrated physical and genetic maps of Glycine max. Nucleic Acids Res 34: D758-D765.

163. Silva AT, Nguyen A, Ye C, Verchot J, Moon JH (2010) Conjugated polymer nanoparticles for effective siRNA delivery to tobacco BY-2 protoplasts. BMC Plant Biol 10: 291

164. Soenen SJ, Manshian B, Doak SH, De Smedt SC, Braeckmans K, et al. (2013) Fluorescent non-porous silica nanoparticles for long-term cell monitoring: cytotoxicity and particle functionality. Acta Biomater 9(11): 9183-9193.

165. Srivastava A, Rao D (2014) Enhancement of seed germination and plant growth of wheat, maize, peanut and garlic using multiwalled carbon nanotubes. Eur Chem Bull 3(5): 502-504.

166. A Xia, M Kovochich, M Liong, H Meng, S Kabehie, et al. (2009) Polyethyleneimine Coating Enhances the Cellular Uptake of Mesoporous Silica Nanoparticles and Allows Safe Delivery of siRNA and DNA Constructs. ACS Nano3(10): 3273-3286.

167. Gaj, C A Gersbach, C F Barbas III (2013) ZFN, TALEN, and CRISPR/ Cas-based methods for genome engineering. Trends Biotechnol 31(7): 397-405.

168. T H Chung, S H Wu, M Yao, C W Lu, Y S Lin, et al. (2007) Biomaterials 28: 2959-2966.

169. T Yu, A Malugin, H Ghandehari (2011) ACS Nano 5: 5717-5728.

170. Torney F, BG Trewyn, V S Y Lin, K Wang (2007) Mesoporous silica nanoparticles deliver DNA and chemicals into plants. Nature Nanotechnology 2: 295-300.

171. Torney F, Trewyn BG, Lin VS-Y, Wang K (2007) Mesoporous silica nanoparticles deliver DNA and chemicals into plants. Nat Nanotechnol 2:295-300.

172. Lachelt, Wagner (2015) Nucleic Acid Therapeutics Using Polyplexes: A Journey of 50 Years (and beyond). Chem Rev 115(19): 11043-11078.

173. Lungwitz M, Breunig T, Blunk A, Gopferich (2005) Polyethyleniminebased non-viral gene delivery systems." Eur J Pharm Biopharm 60(2): 247-266.

174. (2007) USEPA. NanotechnologyWhitePaper:EPA100/B-07/001. Washington, DC: Science Policy Council, US Environmental Protection Agency.

175. Vermeulen SJ, Aggarwal PK, Ainslie A, Angelone C, Campbell BM, et al. (2012) Options for support to agriculture and food security under climate change. Environ Sci Policy 15(1): 136-144.

176. Xue S, Chen H, Yin T, Tammela T, Papagiannakopoulos NS, et al. (2014) CRISPR-mediated direct mutation of cancer genes in the mouse liver. Nature 514(7522): 380-384.

177. Wang L, Huang Y, Kan AT, Tomson MB, Chen W, et al. (2012) Enhanced transport of 2,2',5,5'-493 polychlorinated biphenyl by natural organic matter (NOM) and surfactant-modified fullerene 494 nanoparticles (nC60). Environ Sci Technol 46(10): 5422-5429. 
178. Wang M, Li X, Ma Y, Gu H (2013) Endosomal escape kinetics of mesoporous silica-based system for efficient siRNA delivery. Int J Pharm 448(1): 51-57.

179. Wang X, Miao J, Xia Q, Yang K, Huang X, et al. (2013b) A high sensitivity immunosensor for detection of tumor marker based on functionalized mesoporous silica nanoparticles. Electrochim Acta 112: 473-479.

180. Wang Z, Xie X, Zhao J, Liu X, Feng W, et al. (2012) Xylem-and phloembased transport of $\mathrm{CuO}$ nanoparticles in maize (Zea mays L.). Environ Sci Technol 46(8): 4434-4441.

181. Wang SH, Wang FY, Gao SC, Wang XG (2016) Heavy metal accumulation in different rice cultivars as influenced by foliar application of nanosilicon. Water Air Soil Pollut 227(7): 228.

182. Wiechers JW, Musee N (2010) Engineered inorganic nanoparticles and cosmetics: facts, issues, knowledge gaps and challenges. J Biomed Nanotechnol 6(5): 408-431.

183. Wijnhoven SWP, Peijnenburg WJGM, Herberts CA, Hagens WI, Oomen AG, et al. (2009) Nano-silver - a review of available data and knowledge gaps in human and environmental risk assessment. Nanotoxicology 3(2): 109-138.

184. Gui X He, Y Ma, P Zhang, Y Li, Y Ding, et al. (2015) Quantifying the distribution of ceria nanoparticles in cucumber roots: the influence of labeling. RSC Adv 5(6): 4554-4560.

185. Hu L Mu, J Kang, K Lu, R Zhou, Q Zhou, et al. (2014) Humic Acid Acts as a Natural Antidote of Graphene by Regulating Nanomaterial Translocation and Metabolic Fluxes. Environ Sci Technol 48(12): 6919-6927.

186. Han Z Liu, M Chan Jo, K Zhang, Y Li, Z Zeng, et al. (2015) CRISPR-Cas9 delivery to hard-to-transfect cells via membrane deformation. Sci Adv 1: e1500454.

187. Xiao M, Song F, Jiao J, Wang X, Xu H, et al. (2013) Identification of the gene Pm47 on chromosome 7BS conferring resistance to powdery mildew in the Chinese wheat landrace Hongyanglazi. Theor Appl Genet 126: 1397-1403.

188. Xingmao Ma, C W (2010) Fullerene Nanoparticles Affect the Fate and Uptake of Trichloroethylene in 499 Phytoremediation Systems. Environmental Engineering Science 27(11): 4.

189. Hao, C Ma, Z Zhang, Y Song, W Cao, et al. (2017) Carbon nanomaterials alter plant physiology and soil bacterial community composition in a ricesoil- bacterial ecosystem q Environ. Pollut 232.

190. P Chen, C T Chen, Y Hung, C M Chou, T P Liu, et al. (2013) J Am Chem Soc 135: 1516-1523.

ISSN: 2574-1241

DOI: $10.26717 /$ BJSTR.2021.40.006432

Faran Mustafa. Biomed J Sci \& Tech Res

This work is licensed under Creative

Commons Attribution 4.0 License

Submission Link: https://biomedres.us/submit-manuscript.php
191. Q Fu, L H Li, P W Wang, J Qu, Y P Fu, et al. (2012) Chem Res Chin Univ 28: 672-676.

192. S Lin, C P Tsai, H Y Huang, C T Kuo, Y Hung, et al. (2005) Chem Mater 17: 4570-4573.

193. Yang F, Hong F, You W, Liu C, Gao F, et al. (2006) Influence of nanoanatase $\mathrm{TiO}_{2}$ on the nitrogen metabolism of growing spinach. Biol Trace Elem Res 110: 179-190.

194. Yang L, Watts D J (2005) Particle surface characteristics may play an important role in phytotoxicity of alumina nanoparticles. Toxicol Lett 158(2): 122-132.

195. Yang Z Z, Chen J, Dou R Z, Gao X, Mao C B, et al. (2015) Assessment of the phytotoxicity of metal oxide nanoparticles on two crop plants, maize (Zeamays L.) and rice (OryzasativaL.). Int J Environ Res Public Health 12(12): 15100 -15109.

196. Yu B, J Yang, W Li (2007) In vitro capability of multi-walled carbon nanotubes modifi ed with gonadotrophin releasing hormone on killing cancer cells. Carbon 45(10): 1921-1927.

197. Yuan JS, Galbraith DW, Dai SY, Griffin P, Stewart CN Jr, et al. (2008) Plant systems biology comes of age. Trends Plant Sci 13(4): 165-171.

198. Li J C Barnes, A Bosoy, J F Stoddart, J I Zink (2012) Mesoporous silica nanoparticles in biomedical applications. Chem Soc Rev 41(7): 25902605.

199. Wang X Xie, J Zhao, X Liu, W Feng, JC White, et al. (2012) Xylem- and Phloem-Based Transport of CuO Nanoparticles in Maize (Environ Sci Technol 46(8): 4434-4441.

200. Zhang Z, Kong F, Vardhanabhuti B, Mustapha A, Lin M, et al. (2012) Detection of engineered silver 448 nanoparticle contamination in pears. J Agric Food Chem 60(43): 10762-10767.

201. Zhang L, Wang L, Zhang P, Kan A T, Chen W, et al. (2011) Facilitated transport of $4962,2^{\prime}, 5,5^{\prime}$-polychlorinated biphenyl and phenanthrene by fullerene nanoparticles through sandy soil 497 columns. Environ Sci Technol 45(4): 1341-1348.

202. Zheng L, Hong F, Lu S, Liu C (2005) Effectofnano-TiO2onstrengthof naturally aged seeds and growth of spinach. Biol Trace Elem Res 104(1): 83-91.

203. Zhu H, Han J, Xiao JQ Jin Y (2008) Uptake, translocation, and accumulation of manufactured iron oxide nanoparticles by pumpkin plants. J Environ Monit 10(6): 713-717.

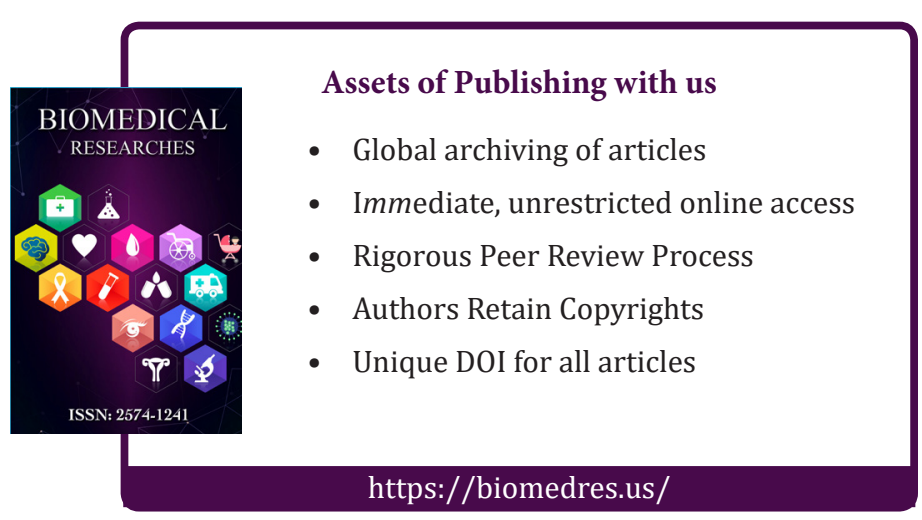

